\title{
Does Kochia prostrata Spread From Seeded Sites? An Evaluation From Southwestern Idaho, USA
}

\author{
Erin C. Gray ${ }^{1}$ and Patricia S. Muir ${ }^{2}$ \\ Authors are ${ }^{1}$ Ecologist, Institute for Applied Ecology, Corvallis, OR 97333, USA; and ${ }^{2}$ Professor, Department of Botany and Plant Pathology, Oregon \\ State University, Corvallis, OR 97331, USA
}

\begin{abstract}
Purposeful introductions of exotic species for rehabilitation efforts following wildfire are common on rangelands in the western United States, though ecological impacts of exotic species in novel environments are often poorly understood. One such introduced species, Kochia prostrata (L.) Schrad (forage kochia) has been seeded on over 200000 ha throughout the Intermountain West to provide fuel breaks and forage, and to compete with invasive plants. Despite its potential benefits, $K$. prostrata has been reported to spread from some seeded areas, and no studies have addressed its potential interactions with native species. A systematic investigation is needed to increase understanding of the extent to which K. prostrata spreads from seeded areas, the environmental conditions under which it spreads, and its interactions with the associated plant communities. We sampled $28 \mathrm{~K}$. prostrata postfire rehabilitation and greenstrip seedings in southwestern Idaho, which ranged from 3 to 24 yr since seeding. We analyzed cover of $K$. prostrata and the associated plant community in adjacent seeded and unseeded areas, and quantified extent of spread from seeded areas. Abundance of K. prostrata was negatively associated with that of most plant functional groups, including native species, but was positively associated with abundance of exotic annual forbs. Kochia prostrata spread to unseeded areas on $89 \%$ of sampled sites; distances of the farthest individual from the seeding boundary were greater than those previously reported, ranging from 0 to $710 \mathrm{~m}$, with a mean distance of $208 \mathrm{~m}$. Further, although the area covered by K. prostrata increased with time since seeding, we found no evidence that plant community composition affected spread of K. prostrata. Results contribute to current understanding of potential ecological implications of seeding K. prostrata and will enhance the ability of land managers to make scientifically based management decisions about its use.
\end{abstract}

Key Words: exotic species, greenstrips, management, sagebrush steppe, slickspots, wildfire

\section{INTRODUCTION}

Purposeful introductions of exotic species for rehabilitation efforts following wildfire or other disturbances are common on rangelands in the western United States, though ecological impacts of exotic species in novel environments are often poorly understood. We studied the commonly seeded species Kochia prostrata (L.) Schrad (forage kochia), which is an introduced species widely seeded throughout western rangelands to stabilize soils, provide fuel breaks and forage, and compete with invasive annual plant species. We assessed its spread from sites onto which it had been seeded in southwestern Idaho, and its relationships to associated plant communities in seeded and adjacent unseeded areas. Results contribute to current understanding of potential ecological implications of seeding $K$. prostrata and will enhance the ability of land managers to make scientifically based management decisions about its use.

Research was funded through the Challenge Cost Share Program with the Idaho Bureau of Land Management and Oregon State University, with additional funding provided by the United States Geological Survey.

At the time of research, Gray was a graduate research assistant, Dept of Botany and Plant Pathology, Oregon State University, Corvallis, OR 97333, USA.

Correspondence: Erin C. Gray, Institute for Applied Ecology, P0 Box 2855, Corvallis, OR 97339, USA. Email: ecgray830@gmail.com

Manuscript received 18 September 2011; manuscript accepted 28 September 2012.

(c) 2013 The Society for Range Management
Over the past century, many sagebrush steppe communities in the Intermountain West have been altered and degraded into exotic grasslands (Chambers et al. 2009; Meinke et al. 2009); it is estimated that $55 \%$ of historical sagebrush steppe remains (Miller et al. 2011). Restoration and rehabilitation efforts in western rangelands face immense challenges, including frequent and intense wildfire, and invasion by exotic species such as Bromus tectorum L. (cheatgrass) and Taeniatherum caputmedusae (L.) Nevski (medusahead) (Chambers and Wisdom 2009). The spatial extent of land converted from historic shrub steppe is vast and the resources required to attempt restoration and rehabilitation on such a scale are lacking (Wisdom and Chambers 2009). Rangeland managers, instead, typically implement localized projects focused on postfire and fuelmanagement treatments (Pellant et al. 2004). Each year, postfire rehabilitation efforts occur on thousands of hectares of public lands in this region, the majority of which are managed by the US Department of the Interior-Bureau of Land Management (USDI-BLM).

In an attempt to prevent the rapid conversion of recently burned areas to highly flammable exotic grasslands, the BLM modified its Emergency Fire Rehabilitation (EFR) Program in 1985 to focus on postfire seeding to promote revegetation of beneficial species and decrease soil erosion (Pellant 1994; Eiswerth et al. 2009). Perennial exotic species, such as Agropyron cristatum (L.) Gaertn. (crested wheatgrass), were often seeded in EFR projects because of their greater establishment success and seed availability when compared to natives (Jones 1999; Brooks and Pyke 2001), and to their high 
forage value (Pellant and Monsen 1993). Although use of native species in postfire rehabilitation is advocated currently, exotic species continue to be seeded regularly because the supply of native seed is limited and seed is expensive (Pellant and Monsen 1993; Richards et al. 1998). For each proposed Burned Area Emergency Stabilization and Rehabilitation plan, managers must justify use of exotic species; justifications must account for their potential impacts on biodiversity and document their inability to spread from seeded areas or to interbreed with native species (USDI-BLM 2007).

In an attempt to prevent spread and impact of wildfires on public land, the Idaho BLM initiated the Greenstripping Program, which occurred from 1985 to 1993. Relatively fireresistant vegetation was planted to create fuel breaks along roads or areas of concern; this program involved seeding 726 $\mathrm{km}$ of greenstrips on BLM land in Idaho with fire-resistant species (Pellant 1994). Species were selected for greenstripping based upon their fire resistance, drought tolerance, capability of establishing and persisting, and palatability (Pellant 1994).

Kochia prostrata (also known as Bassia prostrata [L.] A.J. Scott), a long-lived exotic semievergreen subshrub, has been seeded in postfire rehabilitations and greenstripping programs throughout the western rangelands (Harrison et al. 2000). By 2004, K. prostrata had been seeded on an estimated 202000 ha (Harrison 2004). Kochia prostrata grows in a variety of plant community types including salt desert, sagebrush steppe, and pinyon-juniper woodlands (Stevens et al. 1985; Romo and Haferkamp 1987). It occurs under a range of moisture and temperature regimes, on many soil types, and tolerates highly saline soils (Stevens et al. 1985; Romo and Haferkamp 1987). $K$. prostrata germinates earlier than most native species and has an extensive fibrous root system with a deep taproot, which may enable it to utilize early season soil moisture (Romo and Haferkamp 1987; Waldron et al. 2010a). Kochia prostrata produces thousands of seeds per plant shortly after establishment; seeds are thought to be wind dispersed (Harrison et al. 2000). Its verdant nature contributes to its fire resistance; it is thought to withstand fire and, though it is reported to burn when surrounded by ignitable fuels, it can resprout quickly (Pellant 1994; Harrison et al. 2002).

Although use of $K$. prostrata in rehabilitation offers potential benefits, there are also concerns associated with the introduction of a highly competitive, exotic species into degraded rangelands. All of the mechanisms that enable $K$. prostrata to compete with exotic annuals could also enable it to compete with native species. Its spatial and temporal capacity for water uptake (Romo and Haferkamp 1987) is thought to prevent establishment of annuals and some perennials (Harrison et al. 2000), and its prolific seed production facilitates its recruitment in both annual- and perennial-dominated communities (Stevens et al. 1985). Though its ability to compete with invasive annuals on disturbed sites has been reported (see Monaco et al. 2003; Harrison et al. 2000), little is known about its competitive interaction with native perennial species (Harrison et al. 2000). It has been suggested that $K$. prostrata will not spread into perennial plant communities (Harrison et al. 2000; Waldron et al. 2010a), and that native species may, over time, re-establish in areas dominated by $K$. prostrata (Harrison et al. 2000; Waldron et al. 2001); these suggestions, however, are based on anecdotal observations. Kochia prostrata has been observed to dominate droughty sites, where it might inhibit native species recruitment (Harrison 2004). Some scientists and managers have recommended that $K$. prostrata seedings be limited to greenstrips and fuels management projects and that it not be seeded in large-scale rehabilitation efforts until further research is completed on its interaction with native vegetation (Participants of the Snake River Birds of Prey NCA Habitat Restoration Workshop 1999).

Kochia prostrata has been described as invasive in slickspot and playa communities in southern Idaho, where it might displace the endemic Lepidium papilliferum (L.F. Hend.) A. Nelson \& J.F. Macbr. (slickspot peppergrass) and Lepidium davisii Rollins (Davis' peppergrass) (Tuason 2005; Federal Register 2009; USDI-Fish and Wildlife Service [USDI-FWS] 2010). Both species were previously listed as Idaho sensitive species (Pellant et al. 2004); L. papilliferum was listed in 2009 as threatened under the Endangered Species Act (Federal Register 2009).

Several studies have reported spread of $K$. prostrata from seeded sites (e.g., McArthur et al. 1990; Harrison et al. 2000; Eldridge and Wicklow-Howard 2004), though most unpublished and published reports suggest that claims that it might be invasive are largely unfounded (Harrison et al. 2000; Waldron et al. 2001; Harrison 2004). It has been suggested that spread of $K$. prostrata from seeded areas may be particularly likely when adjacent areas are droughty, highly disturbed and low in productivity; conditions that often occur on low-elevation sites with saline soils (Harrison et al. 2000).

Invasive species pose serious threats to biodiversity and are a significant driver of global change worldwide (Vitousek et al. 1997; Dukes and Mooney 1999). Many accidental or wellintended introductions of exotic species have resulted in invasion of new areas after a lag period (Mack et al. 2000; Brooks and Pyke 2001). Kochia prostrata is a relatively new species in the Great Basin and Columbia Plateau, though it has been planted widely (Harrison 2004). Given that the Great Basin is contains some of the most endangered ecosystems in the United States (Noss et al. 1995), a comprehensive, quantitative study of the potential of $K$. prostrata to spread from seeded sites is necessary to increase understanding of its likely recruitment patterns throughout degraded lands that are targeted for rehabilitation (e.g., Participants of the Snake River Birds of Prey NCA Habitat Restoration Workshop 1999; Harrison et al. 2000; Monaco et al. 2003). Currently, no peerreviewed studies have addressed the potential of $K$. prostrata to spread on western rangelands.

We asked the following questions: What plant communities characterize seeded and unseeded areas 3-24 yr after seeding? Is abundance of $K$. prostrata correlated with environmental variables or abundance of individual plant species or functional groups? Does $K$. prostrata spread from seeded sites, and, if so, to what extent? Does the extent of spread differ among plant communities? What site history or environmental attributes are most strongly associated with extent of its spread? We conducted a systematic investigation of the spreading potential of $K$. prostrata to spread by sampling postfire rehabilitation and greenstrip seedings 3-24 yr after seeding on BLM land throughout the western Snake River Plain and surrounding uplands, Idaho. This study provides insight into the spread potential of $K$. prostrata within a subset of the range of site 
conditions under which it has been seeded. Results contribute to the current understanding of benefits and risks associated with the use of $K$. prostrata in rehabilitation efforts throughout the western rangelands.

\section{METHODS}

\section{Study Area}

Field research was conducted in the summer of 2010 (mid-June through late July) on 28 USDI-BLM postfire rehabilitation and greenstrip seedings located within the western Snake River Plain and surrounding uplands in southwestern Idaho (approximately lat $43^{\circ} 53^{\prime}-42^{\circ} 34^{\prime} \mathrm{N}$, long $116^{\circ} 49^{\prime}-115^{\circ} 2^{\prime} \mathrm{W}$; Fig. S1; available at http://dx.doi.org/10.2111/REM-D-11-00177.s1). Low-elevation sites were located primarily within the relatively flat plains of the Snake River Birds of Prey National Conservation Area (NCA), whereas higher-elevation sites were on the dissected uplands south of the Snake River, between the towns of Mountain Home and Twin Falls; elevations ranged from 770 to $1242 \mathrm{~m}$. Climate in southwestern Idaho is semiarid with hot, dry summers and long, cold winters; most precipitation falls as winter snow and early spring rain (Paige and Ritter 1999). At a centrally located weather station in Mountain Home, mean annual precipitation for the sampling year (2010) was $26.8 \mathrm{~cm}$, which was slightly higher than the historical mean of $25.3 \mathrm{~cm}$ (Western Regional Climate Center 2008). The long-term mean summer maximum temperature is $36^{\circ} \mathrm{C}$, and the mean winter minimum is $-3^{\circ} \mathrm{C}$ (Western Regional Climate Center 2008). Strong winds are common and often originate from the Pacific Ocean or from the eastern end of the Snake River Plain. Soils are largely well-drained silty to stony loams; parent material consists of silty alluvium and volcanic ash over basalt-derived bedrock (US Department of Agriculture-Natural Resources Conservation Service [USDANRCS] 2008).

Plant communities varied among study sites and between seeded and adjacent unseeded areas but were primarily composed of sagebrush steppe and salt-desert shrub community types (Chambers et al. 2009). Bromus tectorum and Poa secunda J. Presl (Sandberg's bluegrass) were typically the dominant plant species. Commonly encountered exotic species included Ceratocephala testiculata [Crantz] Roth (burr buttercup); Sisymbrium altissimum L. (tall tumblemustard); Salsola kali L. (Russian thistle); and Lepidium perfoliatum L. (clasping pepperweed). Artemisia tridentata Nutt. spp. wyomingensis Beetle \& Young (Wyoming big sagebrush; hereafter $A$. tridentata) and Atriplex confertifolia (Torr. \& Frém) S. Watson (shadscale), both native shrub species, were often present in unseeded areas. Seeded species commonly present included $K$. prostrata and A. cristatum.

\section{Field Methods}

Our 28 study sites differed with respect to elevation, topography, and precipitation, and were selected to represent the range of environmental characteristics over which $K$. prostrata has been seeded successfully throughout southwestern Idaho (Table S1; available at http://dx.doi.org/10.2111/ REM-D-11-00177.s1). Candidate sites were selected with the use of the United States Geological Survey (USGS) Land Treatment Digital Library (LTDL) (unpublished data, USGS Land Treatment Digital Library, provided on 8 October 2010), and based on communication with Idaho BLM and USGS employees. Sampled sites included postfire rehabilitation and greenstrip treatments that contained $K$. prostrata in the seeding mix, were seeded by the BLM between 1986 and 2007, and had known seeding boundaries determined largely from shapefiles of seeding treatments (Table S2; available at http://dx.doi.org/ 10.2111/REM-D-11-00177.s1). Restricting sites to ground seedings and greenstrips enabled us to verify seeding boundaries in the field by noting remnant drill rows or obvious changes in species composition. One site had been aerially seeded and two had been both aerially and drill seeded with $K$. prostrata; however, seeding boundaries were verified by agency personnel for these sites. If no shapefile was available, sampling locations were based on visual determination of the seeding boundary, based upon drill rows or natural barriers such as roads and fences. Idaho 2009 1-m NAIP imagery (USDA-Farm Service Agency, Aerial Photography Field Office 2009) was also used to supplement field determination of seeding boundaries when no shapefile was available. Seeding boundaries were often associated with disturbances such as herbicide application, roads, or fire lines. In four cases, what was originally selected as a candidate site contained areas with obviously different plant community types, topographical features, or soil characteristics; these were then treated as two study sites. The modest sample size and restriction of sampling to the western Snake River Plain and surrounding uplands in southwestern Idaho should be borne in mind when evaluating the generality of inferences derived from this study.

Three plots were sampled at each study site; each plot was defined as an adjacent seeded and unseeded area in which plant community composition and spread of $K$. prostrata were sampled. Seeded and unseeded areas, while adjacent, likely had differing disturbance or management histories, which led to seeding a portion of the site but not its entirety; hence, robust inferences about drivers of plant community composition in seeded and unseeded areas cannot be made. Plot locations were determined a priori with the use of geographic information systems (GIS) shapefiles. Multiple random points were created in ArcMap (Environmental Systems Research Institute [ESRI] 2009) along the seeding boundary, and these waypoints were uploaded onto a handheld global positioning system (GPS). In the field, three of these points were randomly chosen for sampling, within the following constraints: accessible adjacent seeded and unseeded areas, width of the seeded area $\geq 65 \mathrm{~m}$, cover of $K$. prostrata within the seeded area $\geq 5 \%$, and $\geq 200$ $\mathrm{m}$ distance from another plot. If a priori plot locations did not fulfill criteria or were inaccessible, plots were positioned by randomly choosing additional locations along the seeding boundary that did fulfill them. For each plot, a center point on the seeding boundary was marked with a handheld GPS, and $15-\mathrm{m}$ buffers, perpendicular to that boundary, were measured into the seeded area and into the unseeded area (Fig. S2; available at http://dx.doi.org/10.2111/ REM-D-11-00177.s1). The buffer was established to accommodate uncertainty about the exact location of the seeding boundary. Within the seeded area, a 50-m transect was established perpendicular to the seeding boundary with the 0 - 
$\mathrm{m}$ point on the seeded edge of the $15-\mathrm{m}$ buffer. Aspect and waypoints for the 0 - and 50-m points were recorded for each transect. We used line-point intercept to record number of hits by species, sampling at $1-\mathrm{m}$ intervals along the transect; numbers of hits were later converted to percent cover, taking into account the number of hits relative to the total number of points sampled along the transect. Substrates (including material present under the vegetative canopy), including rock, moss, biological crust, soil, cow manure, badger mounds, and slickspots were also recorded at $1-\mathrm{m}$ intervals with the use of line-point intercept. Within the unseeded area, a similar 50-m transect was established running $180^{\circ}$ from the first, with the 0 $\mathrm{m}$ mark beginning on the edge of the $15-\mathrm{m}$ buffer into the unseeded area. Sampling along this transect was as previously described.

On sites where $K$. prostrata occurred beyond the seeding boundary, we mapped the recruitment margin along an $\approx 50-\mathrm{m}$ section of the seeding boundary for each plot. We defined the recruitment margin as the outer boundary of the area that supported $K$. prostrata with a density of $\geq 1 \mathrm{plant} \cdot \mathrm{m}^{-2}$. From the center point of each plot, we walked $\approx 25 \mathrm{~m}$ along the seeding boundary and recorded a waypoint with the use of a handheld GPS. From that waypoint we enabled the GPS tracking function to map the path and walked into the unseeded area, parallel to the transect. Once the recruitment margin was reached $(K$. prostrata density became $<1$ plant $\cdot \mathrm{m}^{-2}$ ), we walked the recruitment margin back toward the transect line and beyond it for $\approx 25 \mathrm{~m}$ in the opposite direction. If $K$. prostrata had not spread beyond the seeding boundary or if its density was $<1$ plant $\cdot \mathrm{m}^{-2}$, no recruitment margin was recorded for that plot.

The distance of the farthest $K$. prostrata individual from the seeding boundary was determined for each plot by walking into the unseeded area beyond the end of the $50-\mathrm{m}$ transect, following the same compass bearing as the transect, and conducting an ocular survey for $K$. prostrata across the landscape. A search was conducted with a maximum distance cutoff of $\approx 800 \mathrm{~m}$ and, if a plant was not immediately visible, for a maximum of $15 \mathrm{~min}$ before stopping. Often, small populations or individuals of $K$. prostrata were present in lowlying areas or along roads, so these areas were targeted in the ocular scan. Generally, the locations of three to four plants per plot vicinity were marked, with the use of GPS; the distance of each from the seeding boundary was determined later and data for the farthest of these plants was used in analyses.

\section{Data Preparation}

We gathered site information from the LTDL and project files at Idaho BLM field offices. Soils data were downloaded from the Soil Data Mart (USDA-NRCS 2008) from which we used Map Unit Descriptions (descriptions of the soil taxonomy and topographic positions; Duniway et al. 2010) in conjunction with GIS shapefiles to determine the dominant ecological site characteristics for each plot. Ecological sites are groupings of soil map units that have similar potential to support plant communities and respond to management and disturbance (Duniway et al. 2010). We acquired site-level values for precipitation (PRISM Climate Group 2006), elevation (Idaho Geospatial Data Clearinghouse 2004), and fire history (USDI-
BLM 2009b) with the use of shapefiles in ArcMap (ESRI 2009); center-point values for the three plots per site were used to obtain a mean site-level value. Fire history since seeding was defined as the maximum number of fires that occurred across one or more plots from the year after seeding to 2008 (USDIBLM 2009b); fire history data did not include information on burn intensity or patchiness a burn, and must be interpreted cautiously.

Information on actual livestock use (based on permittees' reports indicating number and kind of livestock, and dates of use) and seasonality were obtained from Idaho BLM field offices. We identified, from shapefiles, the grazing allotment boundaries that encompassed each site and calculated the total area (ha) of each allotment (USDI-BLM 2009a). Grazing is generally restricted for $2 \mathrm{yr}$ after postfire rehabilitation treatments or until objectives have been met (USDI-BLM 2007), so we calculated total annual animal unit months (AUM = amount of forage necessary to sustain one cow or equivalent for a period of one month) per allotment from $2 \mathrm{yr}$ posttreatment to the time of sampling (summer, 2010). We then calculated the mean total annual AUMs for each site for that time period, and divided that by the area of the allotment (ha) to enable comparisons across sites. In cases where some annual AUM data were missing, means were calculated across available data. The coefficient of variation (standard deviation/mean; CV) of total annual AUMs was used to indicate variability in yearly grazing intensity for each site. Where actual use data were not available, we used billed use (AUMs the permittee was billed for) to determine approximate AUMs. When grazing allotments covered significantly more area than our study sites comprised, and grazing records specified detail to the pasture level (smaller areas of an allotment), grazing intensity metrics were calculated at the pasture level.

We calculated two metrics of $K$. prostrata spread, as follows. With the use of the mapped K. prostrata recruitment margin in ArcMap (ESRI 2009), we calculated the area $\left(\mathrm{m}^{2}\right)$ of $K$. prostrata spread and divided it by the actual distance walked along the seeding boundary $(\approx 50 \mathrm{~m}$, measured in ArcMAP) for each plot to determine the mean distance $(\mathrm{m})$ of the recruitment margin from the seeding boundary. The three plot-level distances were averaged to yield one site-level mean distance. Distance of the farthest $K$. prostrata individual (GPS point) from the closest point on the seeding boundary for each plot was measured with the use of ArcMap. The maximum distance of the farthest individual across the three plots per site was used as the distance of the farthest individual for the site.

Percent cover for each species and surface substrate was calculated for each transect; these were averaged to yield site level values. A species matrix (56 sample units $\times 43$ species) was created, which contained mean cover values for each species in adjacent seeded and unseeded areas. Species data were analyzed in relation to an environmental matrix (56 sample units $\times 28$ variables), which included site history information, environmental variables, and cover of substrates. Species were sorted into functional groups by provenance (native or exotic) and life history (annual or perennial; forb, grass, or shrub) characteristics with the use of information from the PLANTS database (USDA-NRCS 2011), and total 
and proportional cover for each group were calculated for each site. A functional group matrix (56 sample units $\times 11$ functional groups) was created, which included total cover for each functional group category (See Gray 2011 for species and functional group lists).

Data transformations and all multivariate analyses were implemented with the use of PC-ORD version 6.0 (McCune and Mefford 2011). Species that occurred in fewer than $5 \%$ of sample units $(n=21)$ were removed from the species matrix, resulting in a matrix of 56 sample units by 22 species. Species and functional group data were square-root transformed to reduce emphasis on the few dominant species or groups. In the environmental matrix, K. prostrata spread distances were $\log _{10}(\mathrm{x}+1)$ transformed, and precipitation values $(\mathrm{mm})$ were $\log _{10}$ transformed to reduce skewness. Surface substrate cover values were square-root transformed to make them comparable to data in the species matrix. Two sample units were identified as outliers (variance $>2$ SD from the mean distance between all sample units); both were low-elevation sites with low diversity, but with high cover for dominant species. Because removal of these outliers did not substantially affect results, and resulted in identification of additional outliers, they were retained in analyses.

\section{DATA ANALYSIS}

\section{Kochia prostrata Abundance in Relation to Plant Community and Environment}

We calculated species richness; Shannon-Wiener diversity; and proportions of cover by K. prostrata, B. tectorum, and native and exotic species for all seeded and unseeded areas. We identified major patterns in community composition and $K$. prostrata abundance, and environmental factors associated with these patterns, with the use of nonmetric multidimensional scaling (NMS) ordinations (Kruskal 1964). NMS is an ordination method that is well suited for community analyses, in which data are often nonnormal and involve nonlinear relationships (McCune and Grace 2002). We ordinated sample units on the basis of both the transformed species matrix and the transformed functional group matrix, with the use of the autopilot setting "slow and thorough" mode (250 runs with real and randomized data, random starting configuration, no penalty for ties) and the Sørensen distance measure. We then assessed relationships (Pearson's correlation) of individual species cover, functional group cover, and environmental variables to the primary gradients in plant communities (ordination axes).

\section{Patterns of $K$. prostrata Spread From Seeded Sites}

To determine if $K$. prostrata had spread from seeded sites, we used distances to the farthest $K$. prostrata individual and mean distances to the recruitment margin to estimate spread at the individual plant and site levels, respectively. To assess temporal patterns in spread, we graphed these distances relative to time since seeding $(\mathrm{yr})$. The rates of spread were then estimated as the slope of linear trend lines (distance $\cdot \mathrm{yr}^{-1}$ ). To determine whether K. prostrata spread differed between communities that currently support or do not support sagebrush-steppe vegeta- tion, we graphed spread metrics in unseeded sites with and without $A$. tridentata relative to time since seeding ( $\mathrm{yr}$ ). Though sites that supported $A$. tridentata were not intact remnant $A$. tridentata communities (many had B. tectorum and an abundance of other exotic species), they were selected as an indicator of historical communities within sampled sites. To explore the dynamics of spread in relation to plant communities and time since seeding, we graphed native species richness for each unseeded site relative to time since seeding ( $\mathrm{yr}$ ), and superimposed distances to the farthest $K$. prostrata individual for each.

\section{Modeling the Spread of $K$. prostrata in Relation to Environment}

To assess whether environmental variables could be used to predict extent of $K$. prostrata spread, we used nonparametric multiplicative regression (NPMR; McCune 2006) in HyperNiche v. 2.10 (McCune and Mefford 2009). NPMR accommodates the fact that species respond to multiple interacting environmental factors by incorporating interactions among predictors, and it also assumes nothing about the shape of the response surface (McCune 2006). NPMR uses an iterative process to create multiple potential models of many combinations of predictors and selects those of best fit, with the use of cross-validation to avoid overfitting.

The response variables (in separate models) were mean distance to recruitment margin $(\mathrm{m})$ and distance of the farthest $K$. prostrata individual $(\mathrm{m})$, both square-root transformed, and predictors were drawn from the transformed environmental matrix described previously. To select candidate predictors, we examined relationships between environmental variables and the measures of $K$. prostrata spread with the use of scatter plots, selecting those with seemingly nonrandom relationships; candidate predictors included time since seeding (yr), elevation $(\mathrm{m})$, mean annual precipitation $(\mathrm{mm})$, mean AUM $\cdot \mathrm{ha}^{-1}$, variability in annual grazing intensity $(\mathrm{CV})$, and cover values $(\%)$ for litter, moss, rock, biological crust, soil, and badger mounds. Models were created with the use of the local mean setting, which estimates the response as an average of observed values, with an automatic minimum neighborhood size $\left(N^{*}\right) . N^{*}$ indicates the amount of data used to obtain a point estimate on the response surface. In NPMR, the estimate for a point on the response surface is weighted depending on its proximity to a data point, with these weights diminishing according to a Gaussian smoothing parameter. Best-fit models were selected based on the leave-one-out cross-validated statistic for fit $\left(\mathrm{x} R^{2}\right)$ which is similar to the conventional $R^{2}$; however, point data are excluded when calculating the mean, resulting in the possibility of a negative $\mathrm{x} R^{2}$ for a weak model (McCune 2006). Predictors were evaluated with the use of sensitivity analysis, in which sensitivity of a predictor is determined by the magnitude of change in response of the model caused by altering that predictor; predictors with higher sensitivity have more influence on model response. Statistical significance of the whole model is evaluated with the use of a randomization test to determine if the fit of the selected model is better than that expected by chance (McCune 2006). 


\section{RESULTS}

\section{Kochia prostrata Abundance in Relation to Plant Community and Environment}

We recorded 43 plant species across the 28 sites and 168 transects ( 84 seeded and 84 unseeded); 22 species were native and 17 were exotic, with 4 unknown species (see Gray 2011 for a species list). Across seeded and unseeded areas, site-level mean total plant cover was $110.2 \%$ (cover can exceed 100\% when point-intercept sample pins encounter multiple layers of vegetation), with mean species richness $(S)$ of 7.1 and mean Shannon-Wiener $\left(H^{\prime}\right)$ diversity of 1.3 . Mean species richness and Shannon-Wiener diversity in seeded areas were 6.0 $(\mathrm{SE}=0.42)$ and $1.14(\mathrm{SE}=0.04)$, respectively, and in unseeded areas were $7.9(\mathrm{SE}=0.48)$ and $1.39(\mathrm{SE}=0.05)$, respectively. Mean total plant cover was $116.8 \%(\mathrm{SE}=5.6)$ in seeded areas and $103.6 \%(\mathrm{SE}=4.8)$ in unseeded areas; mean foliar cover as a monolayer was $79.2 \%$ (bare ground $=20.8 \%, \mathrm{SE}=2.9$ ) in seeded areas and $83.9 \%$ (bare ground $=16.1 \%, \mathrm{SE}=3.0$ ) in unseeded areas.

Seeded and unseeded areas had both similarities and differences in proportions of cover by various species and functional groups. Mean proportions of total cover by exotic species (omitting $K$. prostrata, as it was seeded) within unseeded and seeded areas were $0.54(\mathrm{SE}=0.04)$ and 0.48 $(\mathrm{SE}=0.04)$, respectively. Seeded and unseeded sites supported similar proportions of $B$. tectorum cover (means $=0.22$ $[\mathrm{SE}=0.05]$ and $0.26[\mathrm{SE}=0.04])$. Total proportions of $K$. prostrata cover ranged from 0.10 to 0.72 in seeded areas and 0 to 0.68 in unseeded areas; mean proportions of $K$. prostrata cover were greater within seeded than in unseeded areas (means $=0.27$ and 0.09 , respectively). Native species tended to comprise higher proportions of cover in unseeded than in seeded areas (means $=0.37[\mathrm{SE}=0.04]$ and $0.25[\mathrm{SE}=0.05]$ ).

An NMS ordination of sample units in functional group space resulted in a stable 3-dimensional solution (final stress $=11.1$, final instability $<0.0001$, Fig. 1). A randomization test confirmed that the final stress was lower than expected by chance $(P=0.004)$. Cumulatively, the three axes explained $95 \%$ of the variance in functional group cover, with Axis 1 explaining the majority $(73 \%)$, and Axes 2 and 3 sharing the remainder (10 and $12 \%$, respectively). Seeded and unseeded sample units tended to be intermixed in the ordination space. Kochia prostrata was the only exotic perennial shrub, and it had a strong and positive correlation with Axis $1(r=0.75)$, as did cover of exotic annual forbs $(r=0.77)$. Exotic perennial grasses $(r=-0.70)$, exotic annual grasses (B. tectorum; $r=-0.73)$, native perennial grasses $(r=-0.73)$, and native perennial shrubs $(r=-0.41)$ all had strong negative relationships with Axis 1 . Axis 1 was also negatively correlated with elevation and cover by fine litter and positively correlated with yearly variation in grazing intensity and biological crust cover.

Axis 2 was positively correlated with cover by native perennial grasses $(r=0.51)$ and native annual forbs $(r=0.45)$; whereas exotic perennial shrubs $(r=-0.44)$ and exotic annual grasses $(r=-0.43)$ were negatively correlated with this axis. Cover by moss was the only environmental variable strongly correlated with this axis $(r=0.54$; all others $<0.4)$. Axis 3 was positively correlated with cover of exotic annual grasses

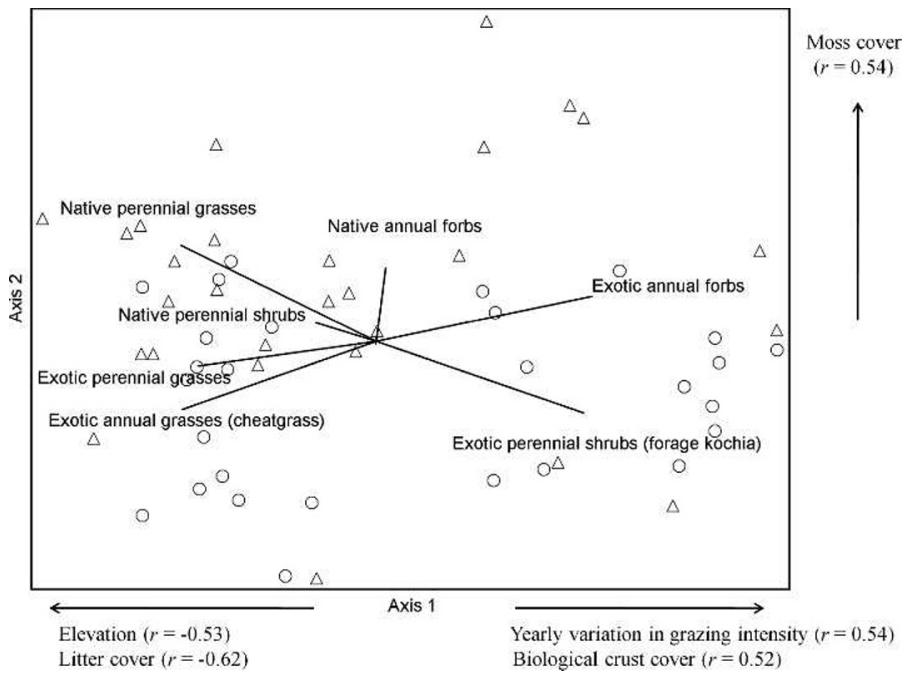

Figure 1. Nonmetric multidimensional scaling ordination of sample units in functional group space, with overlays of functional groups. Points represent sample units, and distance between points indicates their similarity in functional group composition. Circles represent seeded sample units and triangles represent unseeded sample units. Functional groups with notable correlations $(r>0.40)$ with ordination axes are indicated by vector lines on the ordination diagram, with the length of the line representing the strength of the correlation; environmental variables correlated $(r>0.40)$ with ordination axes are indicated along the margins.

$(r=0.47)$; however, it was not strongly correlated with any of the environmental variables (maximum $r=0.36$ ).

The NMS ordination of sample units in species space indicated similar relationships to those revealed by the functional group ordination, with intermixing of seeded and unseeded sample units and a primary axis strongly correlated with $K$. prostrata cover $(r=0.83)$. This ordination, however, identified additional environmental correlates; years since seeding $(r=0.49)$, number of fires since seeding $(r=0.42)$, and silty soils $(r=0.45)$ were positively correlated with the primary axis, whereas mean grazing intensity $(r=-0.50)$ and mean annual precipitation $(r=-0.41)$ were negatively correlated with this axis. Species negatively correlated with this axis included the exotic $B$. tectorum $(r=-0.74)$, seeded $A$. cristatum $(r=-0.62)$, and natives $P$. secunda $(r=-0.70)$ and $A$. tridentata $(r=-0.43)$. Species positively correlated with this axis included the exotic forbs C. testiculata $(r=0.85)$ and L. perfoliatum $(r=0.41)$.

\section{Patterns of $K$. prostrata Spread From Seeded Sites}

Kochia prostrata spread from $89 \%$ of sampled seeded sites. Distances of the farthest $K$. prostrata individual from the seeding boundary ranged from 0 to $710 \mathrm{~m}$ with a mean distance of $208 \mathrm{~m}$ (Fig. 2A). Distance increased with time since seeding $\left(r^{2}=0.47\right)$, with an estimated mean rate of spread of 25 $\mathrm{m} \cdot \mathrm{yr}^{-1}$. Distances to the recruitment margin ranged from 0 to $197 \mathrm{~m}$, with a mean distance of $30 \mathrm{~m}$ (Fig. 2B). The distance to the recruitment margin also increased with time since seeding $\left(r^{2}=0.50\right)$ with an estimated mean rate of expansion of the initial seeding of $4 \mathrm{~m} \cdot \mathrm{yr}^{-1}$. Seventy-five percent of sampled sites had a measurable recruitment margin. Kochia prostrata spread into unseeded areas with and without A. tridentata (Fig. 


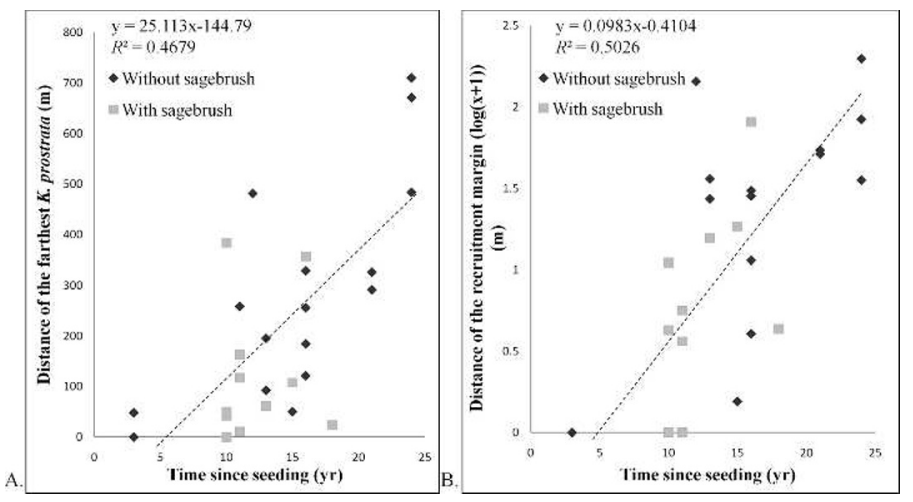

Figure 2. Distance of the farthest Kochia prostrata plant $(\mathrm{m})$ from the seeding boundary $(A)$ and mean distance of the recruitment margin $(\mathrm{m})$ $(\log x+1$ scaled) from the seeding boundary (B), relative to time since seeding. Points represent unseeded sample units with and without Artemisia tridentata.

2). In the 12 unseeded areas in which A. tridentata was present, distance to the recruitment margin ranged from 0 to $80 \mathrm{~m}$, with an average of $11 \mathrm{~m}$. Distance of the farthest $K$. prostrata individual in these sites ranged from 0 to $357 \mathrm{~m}$, with an average of $110 \mathrm{~m}$. Because of differences in ranges of years since seeding between sites with $A$. tridentata and those without (10-18 yr and 3-24 yr, respectively), direct comparisons of spread between the two types of communities cannot be made; no differences within the 10-18-yr range were apparent. No clear patterns of spread in relation to other vegetative attributes of unseeded areas were apparent. Native species richness in unseeded areas ranged from 0 to 9 species, and distances to the farthest $K$. prostrata individual varied widely across these sites (Fig. 3); greatest distances of spread occurred in sites that were seeded longest ago, which also had relatively low native species richness. Both metrics of spread were greater at lower $(<1000 \mathrm{~m} ; n=18$ sites $)$ than at higher elevations ( $>1000 \mathrm{~m} ; n=10$ sites). Mean distances to the recruitment margin were 45 and $1 \mathrm{~m}$, and mean distances to the farthest $K$. prostrata individual were 283 and $71 \mathrm{~m}$ for lowerand higher-elevation sites, respectively.

\section{Modeling the Spread of $K$. prostrata in Relation to Environment}

NPMR models for spread of $K$. prostrata (mean distances of recruitment margin and to farthest $K$. prostrata individuals from the seeding boundary) had fits that were better than expected by chance (Table 1), and both explained a large percentage of the variation in spread distances. The strongest model for spread in terms of distance to the recruitment margin included three predictors: variability in yearly grazing intensities, soil cover (lack of cover by other substrates), and elevation. Although relationships to predictors were not linear, in general, distance of the recruitment margin decreased with elevation and increased with variability in yearly grazing intensity and soil cover. The strongest model for distance of the farthest $K$. prostrata individual included predictors of years since seeding, rock cover, and badger mound cover. Although relationships to predictors were not linear, distance of the

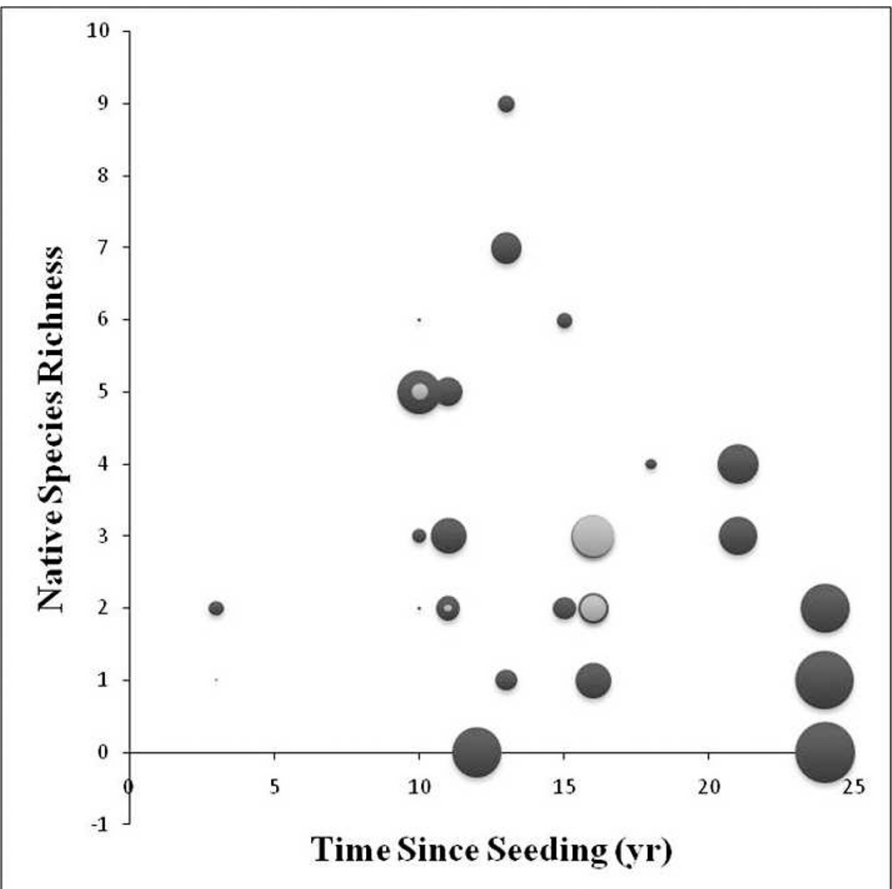

Figure 3. Native species richness in unseeded areas relative to time since seeding of adjacent seeded areas. Points represent unseeded sample units and the size represents distance of the farthest Kochia prostrata individual (m) for each sample unit (distances ranges from 0 to $710 \mathrm{~m}$ ). Some points represent two sample units with differing spread differences (noted by light and dark gray points overlapping).

farthest $K$. prostrata individual tended to increase with years since seeding, rock cover, and badger mound cover.

\section{DISCUSSION}

\section{Kochia prostrata Abundance in Relation to Plant Community and Environment}

Differences in plant communities between adjacent seeded and unseeded areas are likely a result of diverse disturbance and management histories, with management including seeding with $K$. prostrata. The lack of preseeding data on these communities coupled with our modest sample size limit inference about effects of seeding on them; results, however, may provide insights into plant community outcomes 3-24 yr after postfire rehabilitation and greenstripping treatments that include seeding with $K$. prostrata. Specific objectives for Emergency Fire Rehabilitations include restoring or establishing healthy ecosystems to provide habitat for sagebrushobligate wildlife species, while deterring establishment of invasive exotic species (Eiswerth et al. 2009). The tendency for Shannon-Wiener diversity, species richness, and proportions of cover by natives to be higher in unseeded than in seeded areas suggest that seeding efforts may not result in diverse plant communities, at least over the time scale encompassed by this study. Objectives for greenstrip seedings differ from those for postfire rehabilitations, and include reducing fire-suppression costs and losses of plant diversity and shrub cover, properties and structures (Pellant 1994). 
Table 1. Nonparametric multiplicative regression models of Kochia prostrata spread (mean distances of recruitment margin and of farthest $K$. prostrata individuals from the seeding boundary) in relation to environmental predictors. $\mathrm{X} R^{2}=$ leave-one-out cross-validated statistic for fit. Average $N^{*}=$ amount of data used to obtain a particular point estimate. Sensitivity = relative strength of each predictor, indicating the magnitude of change in model response from changing a predictor value; high values indicate greater magnitude of response. Tolerance $=$ the range of predictor space over which data values are used to estimate response (sensitive to scale of data); predictors with narrow tolerances have greater effects on the model than do those with broad tolerances.

\begin{tabular}{lcc}
\hline \multicolumn{1}{c}{ Measure of spread } & $\begin{array}{c}\text { Recruitment } \\
\text { margin }(\mathrm{m})\end{array}$ & $\begin{array}{c}\text { Distance to farthest } \\
\text { K. prostrata }(\mathrm{m})\end{array}$ \\
\hline $\mathrm{X} R^{2}$ & 0.81 & 0.64 \\
$p$ & 0.01 & 0.02 \\
Average $N^{*}$ & 1.67 & 2.24 \\
Sensitivity (tolerance) & - & $0.05(0.32)$ \\
Badger mound cover (\%) & $1.07(2.77)$ & - \\
Coefficient of variation of yearly grazing & $0.04(169)$ & - \\
levationn (m) & - & $0.12(0.83)$ \\
ock cover (\%) & $0.32(0.57)$ & - \\
Soil cover (\%) & - & $0.63(1.47)$ \\
Years since seeding & & \\
\hline
\end{tabular}

Though greenstrips may be effective in reducing fuel continuity (Pellant 1994; Harrison et al. 2002), those seeded with K. prostrata may not fulfill objectives related to maintaining plant diversity within seeded areas.

Kochia prostrata was present in both seeded and unseeded areas, and its abundance varied across sites. The species dominated some seeded areas, particularly in low-elevation sites $(850-1000 \mathrm{~m})$; those with the greatest proportions of cover by $K$. prostrata $(\geq 0.5 ; n=5)$ also included large proportions of cover by exotic annual forbs, with only small proportions of native species present. Disturbance associated with fire history and seeding activities may have depleted species' populations in the seeded areas, and likely affected species composition in these areas. Lack of other species could increase the potential for $K$. prostrata to dominate some seeded sites. Though $K$. prostrata is seeded in part to compete with invasive annual grasses (McArthur et al. 1990; Harrison et al. 2000; Monaco et al. 2003), proportions of B. tectorum cover were similar across seeded and unseeded areas. In one site, $K$. prostrata dominated the unseeded area (proportion of cover $=0.68$ ), with the remainder of vegetation also composed exclusively of exotic species. Although mean proportions of $K$. prostrata cover were greater in seeded than in unseeded areas, the mean proportion across the unseeded areas was substantial (one third of that in the seeded area), indicating potential to dominate even unseeded areas.

Kochia prostrata abundance was positively associated with silty soils, and negatively associated with elevation and precipitation, and similar environmental associations have been noted in other studies (Waldron et al. 2001, 2010b). Kochia prostrata may be able to persist on low-elevation, lowprecipitation sites on which other species may be moisture limited (Monaco et al. 2003; Newhall et al. 2004), because of its drought tolerance and ability to utilize soil moisture early in the season (Romo and Haferkamp 1987; Leonard et al. 2008). For many known competitive and invasive plant species in the Intermountain West, the ability to utilize soil moisture early in the season is considered to confer an important competitive advantage (Chambers et al. 2007). Kochia prostrata shares this ability with other highly competitive species such as $A$. cristatum, B. tectorum, and T. caput-medusae, which, by preempting resources, can adversely affect native species establishment (Eissenstat and Caldwell 1988; Melgoza and Nowak 1991; Chambers et al. 1994). In addition to its ability to utilize early-season moisture, $K$. prostrata is a $\mathrm{C}_{4}$ species, unlike many species in western rangelands, which utilize $\mathrm{C}_{3}$ metabolism. Its $\mathrm{C}_{4}$ metabolism enhances its drought tolerance and water-use efficiency at high temperatures (Pyankov et al. 2001; Leonard et al. 2008). Further, as a halophyte, K. prostrata is salt tolerant during multiple stages of its life cycle (Romo and Haferkamp 1987) and is able to accumulate salts that increase its internal osmotic potential, further enhance its drought tolerance, and enable it to persist in highly saline soils (Karimi et al. 2005). Though no studies have directly investigated the roles of water relations in $K$. prostrata's interspecific interactions, future studies should address the possibility that its competitive ability could negatively affect native species' growth and establishment. The relatively low abundance of K. prostrata at higher-elevation and -precipitation sites could be at least partially a result of increased competition from more prevalent native species, and lessened competitive advantage associated with its drought tolerance and water-extraction capabilities (Chambers et al. 2007).

Although there are examples of $K$. prostrata competing with and reducing abundance of B. tectorum (McArthur et al. 1990; Monaco et al. 2003), little information exists on interactions between $K$. prostrata and native species. Though we did not study competition explicitly and the lack of preseeding data limits inference, trends in occurrence of $K$. prostrata and various plant functional groups in ordination space suggest potential interactions. Kochia prostrata abundance was negatively correlated with that of most functional groups, including native perennial grasses, native perennial shrubs, exotic perennial grasses, and exotic annual grasses (B. tectorum), and was positively correlated only with abundance of exotic annual forbs. These patterns in relative abundance of most functional groups could suggest competitive interactions between $K$. prostrata and other species, both native and exotic. Although some reports speculate that K. prostrata's competitive influence affects only exotic annuals (Harrison et al. 2000), our results did not indicate differences between exotic annual grasses' and native species' abundance in relation to $K$. prostrata. On the contrary, $K$. prostrata's positive relationship to exotic annual forbs in functional group space may suggest a lack of competitive interactions, or that other forces are more influential than such interactions. For example, we observed an apparently positive species association between $K$. prostrata and Ceratocephala testiculata, an exotic annual forb, whose seedlings (based on early spring [March 2010] field observations at low-elevation sites) were commonly present under the canopy of $K$. prostrata. This could be a case of $K$. prostrata facilitating an early-season annual, although experimental studies would be necessary to elucidate causation. Though the general patterns of species occurrence that we documented 
may be caused by interspecific interactions, they could also result from disturbance prior to and during seeding and proximity, or lack thereof, to native seed sources. Experimental and longer-term studies of interactions between $K$. prostrata and other species would increase understanding of its effects on them.

Time was an important factor related to $K$. prostrata abundance; its abundance increased on both seeded and unseeded sites with number of years since seeding. Though $K$. prostrata is thought to live up to $15 \mathrm{yr}$ (Balyan 1972), sites that were seeded up to $24 \mathrm{yr}$ prior to our sampling supported high $K$. prostrata abundance, suggesting that it has established selfperpetuating populations. Within seeded areas and in the recruitment margin, $K$. prostrata appeared to be self-limiting; early in the season many seedlings had established around reproductive individuals; however, by late summer many of the seedlings had died. A similar phenomenon has been noted in salt-desert habitats (Monaco et al. 2003).

Our data suggest that livestock grazing intensity may affect patterns in $K$. prostrata abundance. Inferences about patterns in $K$. prostrata abundance in relation to grazing based on our study must, however, be made cautiously, given that field data are observational and that grazing data were derived from actual use data provided by the BLM. Although actual use data are often used to estimate grazing pressure (e.g., Lym and Kirby 1987; Hickman 2004), they are self-reported by permittees and also do not take into account livestock forage preferences or heterogeneity in grazing depending on water availability, which could affect species' abundances and responses to grazing pressures. Kochia prostrata abundance tended to be higher on sites that had relatively variable intensities of grazing, but lower on sites that had been grazed at relatively high intensities (mean annual AUM $\cdot \mathrm{ha}^{-1}$ ranged from 0 to 0.7 , with CVs of AUMs ranging from 0 to 0.69 ). Pregrazing biomass and branch density were strong predictors of $K$. prostrata biomass consumption in cattle preference studies (Waldron et al. $2010 \mathrm{~b}$ ), and year-to-year variability in grazing could allow for recovery of branch density and biomass, and hence cover, after high-intensity years. Kochia prostrata biomass increased with grazing intensity in comparisons of grazed and ungrazed sites in Mongolia (Chen et al. 2005), suggesting that some grazing stimulates growth, as has been noted for other aridland shrubs (Bilbrough and Richards 1993). On the other hand, consistently high grazing intensity could decrease branch density to the point where seed production and growth of $K$. prostrata were inhibited. Decline in K. prostrata abundance has been observed in studies of the effects of increasing grazing pressure on the species in northwestern China (Zhao et al. 2007), and negative effects are thought to occur when $K$. prostrata is grazed to a height of less than $5 \mathrm{~cm}$ (USDA-NRCS 2011).

Though effects of season of grazing on $K$. prostrata abundance were difficult to assess because most sites had been grazed in similar seasons (primarily winter and spring), its cover could be reduced if high-intensity grazing occurred in early spring when the plant allocates energy to flowering and fruiting (Harrison et al. 2000; USDA-NRCS 2011). Cattle selectively graze inflorescences prior to consuming leaves and vegetative stems (Davenport 2005), which could affect abundance by diminishing recruitment of new plants. Though some have noted that $K$. prostrata is rarely grazed in the spring, when other species are preferred (USDA-NRCS 2011), on sites lacking perennial grasses and on which $K$. prostrata is dominant, spring grazing might negatively affect its abundance and potential to spread. Experimental investigations on effects of grazing intensities and seasonality on $K$. prostrata abundance would enhance understanding of consequences of alternative grazing management strategies for this species.

Disturbance influences K. prostrata abundance (McArthur et al. 1990; Waldron et al. 2001), and we found that its abundance and the number of fires since seeding were positively associated. (Number of fires since seeding, which ranged from 0 to 2 , and time since seeding were not correlated, so the relationship of $K$. prostrata abundance to numbers of fires is not simply an artifact of more time having allowed for more fires.) Increased abundance of $K$. prostrata with increasing fire could result at least partly from its reported fire tolerance, ability to resprout after fire (McArthur et al. 1990; Harrison et al. 2002), and release from less fire-tolerant competitors. Although K. prostrata does not have a persistent seed bank and has been noted to burn when surrounded by fine fuels in highintensity fires, its ability to resprout after fire confers the ability to withstand repeated fire and, potentially, to increase in abundance after consecutive fires. These attributes may enable it to dominate plant communities such as salt-desert shrub, which were not historically adapted to fire but which now burn more frequently than in the past (Chambers et al. 2009), as well as plant communities that were adapted to a regime of lessfrequent fire than now prevails (Brooks and Pyke 2001).

Kochia prostrata abundance was positively associated with biological crust cover and negatively associated with litter and moss cover; all might reflect disturbance within the community and interactions with other species. Presence of B. tectorum increases cover of fine litter (Belnap and Phillips 2001; Evans et al. 2001), and this, coupled with the negative relationship we observed between abundances of K. prostrata and B. tectorum across sample units, could account for the negative association between $K$. prostrata and litter cover. The positive relationship between cover of biological crusts and $K$. prostrata may reflect gradients in grazing intensity or abundance of B. tectorum. Biological soil crusts are sensitive to physical disturbance (Belnap and Eldridge 2001; Ponzetti and McCune 2001), and we found lower abundance of $K$. prostrata on sites that were grazed most intensely, which also had lower cover by crusts. Biological crust and B. tectorum cover have been reported to be negatively related (Ponzetti et al. 2007), which could also account for the positive association between crust and $K$. prostrata cover that we observed. Kochia prostrata is thought to recruit on bare soil and in the interspaces between plants (Harrison et al. 2000), which might explain the negative relationship of $K$. prostrata cover with that of moss, which also occupies these regions.

\section{Patterns of $K$. prostrata Spread From Seeded Sites}

The measured distance of the farthest K. prostrata individual from the seeding boundary $(710 \mathrm{~m})$ is likely a conservative estimate of potential spread. We limited the search distance to $800 \mathrm{~m}$ because of time constraints, and it is likely that other individuals occurred past the marked individuals. Further, there 
were often large relatively isolated patches of $K$. prostrata beyond the mapped recruitment margin, indicating that this measurement also likely underestimated expansion of the initial seeding. In many exotic species invasions, spread can occur via satellite patches that become new seed sources for invasion (Moody and Mack 1988; Archer and Pyke 1991). This pattern was observed in unseeded areas, where recruitment of $K$. prostrata occurred not only as spread from the immediately adjacent seeded area but also from more disjunct patches; individuals marked as the farthest $K$. prostrata often occurred in small satellite populations, sometimes far from the seeding boundary.

Distances over which $K$. prostrata spread were greater than previously reported by others in research reports and proceedings. For example, sites located throughout the Great Basin (10-30 yr after seeding) had mean and maximum distances to a single plant in unseeded areas of 28 and $386 \mathrm{~m}$, respectively (Harrison et al. 2000), whereas in our study these were 208 and $710 \mathrm{~m}$, respectively. In another study, K. prostrata spread $>400 \mathrm{~m}$ across a B. tectorum-invaded field and into an A. tridentata community over $17 \mathrm{yr}$ (McArthur et al. 1990); this distance is more comparable to distances that we measured. Differences in reported spread could result from differences in site conditions or accuracy of determining seeding boundaries. We selected sites with known seeding boundaries, and although most were ground seeded, two sites had been both ground and aerially seeded and another had been aerially seeded. Though it is unknown how far seeds can travel outside of seeding boundaries in aerial seedings, we found little difference in spread distances when aerially seeded sites were removed from the analysis (mean distance to the recruitment margin with and without aerial seedings $=30$ and $28 \mathrm{~m}$, respectively; mean distance to the farthest individual with and without aerial seedings $=208$ and $206 \mathrm{~m}$, respectively). Though reports claim that concerns about spread of $K$. prostrata are "largely unfounded" (Harrison et al. 2000) it is clear that the species does spread into areas where it was not seeded.

Both metrics of spread increased linearly with time, indicating continued potential for further spread. Though the $4-\mathrm{m} \cdot \mathrm{yr}^{-1}$ rate of increase in distance of the recruitment margin from the seeding boundary may seem slow compared to some invasions, continued spread at this rate could substantially increase the extent of $K$. prostrata on the landscape, with greater proportional increases for relatively small seeded areas. For example, for a hypothetical circular seeded site with area equal to the smallest seeded area we sampled ( 8 ha) and whose radius increased by $4 \mathrm{~m} \cdot \mathrm{yr}^{-1}$, the area occupied by $K$. prostrata at densities $\geq 1$ plant $\cdot \mathrm{m}^{-2}$ would be twice that of the original seeded area within $17 \mathrm{yr}$, and within $25 \mathrm{yr}$, its extent would equal nearly $265 \%$ of the original seeded area. For a hypothetical circular area with area equal to the largest seeded area sampled (1841 ha) and from which $K$. prostrata was spreading at $4 \mathrm{~m} \cdot \mathrm{yr}^{-1}$, the area occupied by K. prostrata at this density would equal approximately $108 \%$ of the original seeded area within $25 \mathrm{yr}$. These scenarios demonstrate clearly that $K$. prostrata may, over time, greatly increase the area that it occupies compared to the original size of the seeding, with greater effects for smaller seedings.

We found no evidence that plant community composition affected spread of $K$. prostrata; trends in relation to species composition must be interpreted cautiously because of our modest sample size and because spread distances increased with time since seeding. Spread occurred into unseeded sites containing A. tridentata, sites with relatively high abundance of native perennial grasses (up to $66 \%$ of foliar cover), as well as those dominated by exotic annuals. These results are contrary to reports that suggest that $K$. prostrata will not spread into perennial plant stands (Waldron et al. 2001). Many report also that $K$. prostrata will spread into disturbed sites only when competition is limited (e.g., Waldron et al. 2001); however, our results suggest that spread was not restricted to exotic-species-invaded, highly degraded areas that supported particularly low plant cover.

Kochia prostrata spread into unseeded areas on sites containing slickspots that are habitat for the federally threatened $L$. papilliferum, and the Idaho sensitive species L. davisii, both endemic to these harsh saline habitats (Moseley 1994; Federal Register 2009). Others have suggested that invasion of $K$. prostrata into highly saline slickspots may negatively impact abundance of both Lepidium species (Tuason 2005; Federal Register 2009; USDI-FWS 2010). We found highest abundances of $K$. prostrata on low-elevation sites with silty soil, which are also areas in which slickspots and playas occur in southern Idaho; slickspots could often be located visually in unseeded areas because of their high abundance of $K$. prostrata. Currently, the BLM recommends restricted use of $K$. prostrata when seeding around slickspot habitat to protect populations of L. papilliferum and L. davisii (USDI-BLM 2010), and BLM emergency fire rehabilitation plans do not allow planting of $K$. prostrata within a 402-m buffer surrounding slickspots. Our results demonstrate that $K$. prostrata can spread farther than $402 \mathrm{~m}$ under similar environmental conditions, and suggest that its potential to spread great distances from the seeding boundary over time should be taken into account when considering use of this species.

The fact that distance to the recruitment margin was most strongly predicted by variability of yearly grazing intensity suggests that grazing affects not only $K$. prostrata abundance but also its spread. Soil cover was also a positive predictor of spread, which may reflect that bare soil is necessary for its establishment. Finally, elevation tended to be a negative predictor of $K$. prostrata spread as indicated by distance to the recruitment margin, consistent with its pattern of lower abundance at higher elevations. The strongest predictor for distance of the farthest individual was years since seeding, corroborating that time since seeding influences both abundance and spread into unseeded sites. Cover by rock and badger mounds were also positive predictors of distances to the farthest individual. Relatively high rock cover might indicate areas with less vegetation and more differentiated microsites in which $K$. prostrata could establish. American badger (Taxidea taxus) mounds are highly abundant throughout southwestern Idaho and create ubiquitous disturbance (Eldridge 2004), into which $K$. prostrata is thought to preferentially spread (Harrison et al. 2000).

Humans have facilitated many plant invasions (e.g., Mack et al. 2000; Brooks and Pyke 2001) and anthropogenic forces should be considered when addressing invasion potential of a purposefully introduced exotic species. Though K. prostrata seed is primarily dispersed by wind, we found individual plants along roadsides and vehicle tracks in unseeded areas. These may have originated from seed conveyed by vehicles and their 
establishment may have been enhanced by associated disturbances; roads are known conduits for invasion of unwanted species in semiarid landscapes (Gelbard and Belnap 2003; Pyke and Knick 2003). Use of off-road vehicles in sites seeded with $K$. prostrata and adjacent unseeded areas could increase spread in these highly disturbed landscapes. Other anthropogenic influences could also affect $K$. prostrata abundance and spread. For example, the BLM issues permits for collection of $K$. prostrata seed from seeded sites that are primarily composed of K. prostrata (C. Fritz, USDI-BLM, personal communication, 1 April 2011). The species' abundance and spread may be lowered on sites from which seed is harvested often.

It has been suggested that $K$. prostrata could compete with annual grasses following fire and promote native species establishment by lessening competition from exotic species (Harrison et al. 2000). Though use of $K$. prostrata is often justified on this basis, evidence in support of its facilitating establishment of native species is anecdotal, and no published studies have previously assessed the potential of native species to become established in K. prostrata seedings. We found that native vegetation occurred only sparsely in $K$. prostrata seedings that were 3-24 yr old. Native species have been included in seed mixes with $K$. prostrata in some plantings; however, little information exists on the success of these seedings; native establishment has been limited when sites were seeded with A. cristatum, another exotic species often seeded for rehabilitation efforts (Thompson et al. 2006). More research should be conducted on the ability of native species to establish naturally in $K$. prostrata seedings on a range of sites, and on the potential for native species to be seeded successfully into established $K$. prostrata stands.

Many well-intended introductions, such as those of $A$. cristatum, have resulted in unwanted interactions with native species. Establishing native species in A. cristatum monocultures has become a restoration priority, and control methods for this species are being explored (Hulet et al. 2010). Kochia prostrata is considered a highly adaptable species (Waldron et al. 2001), and though it has been seeded widely, it is still a relatively new species on the landscape. Kochia prostrata is now established in a variety of ecosystem types, and little is known about how that establishment may affect diversity and resilience of these systems, or of other ecosystems into which it may be introduced in the future (Thorpe et al. 2011). Much like many Eurasian species that have become problematic in the United States, K. prostrata behaves differently in its introduced range than it does in its native habitat, where it reportedly does not grow in pure stands or spread from seeded areas (Waldron et al. 2001). These differences in population dynamics may indicate potential for its establishment to have unanticipated consequences for native species.

\section{MANAGEMENT IMPLICATIONS}

When selecting species for rehabilitation efforts, land managers must consider potential benefits and costs, including trade-offs concerning species diversity and ecosystem functioning (Chambers et al. 2009). Federal agencies now emphasize the use of native species in rehabilitation efforts, and managers must justify use of exotic species, planting them only if doing so will not diminish plant diversity and the species will remain confined within the management area (USDI-BLM 2007). Our study demonstrated that K. prostrata did not remain confined to seeded areas across most sampled sites, nor was its spread restricted to plant communities dominated by annuals. Further, although conditions prior to seeding are unknown, plant diversity tended to be lower on sites seeded with $K$. prostrata than in adjacent unseeded areas even up to $24 \mathrm{yr}$ postplanting. Given the highly disturbed nature of many of the sites into which $K$. prostrata has been introduced and recent Federal mandates (USDI-BLM 2007), a clear rationale is necessary to justify use of this exotic species, particularly given that peer-reviewed literature addressing its potential competitive interactions with native species is lacking. Land managers should be especially cautious under the environmental conditions that seem most conducive to its spread, including those found in low-elevation areas with silty soils, particularly on sites containing slickspots. Managers should also take into account the low abundance of $K$. prostrata in seeded areas at higher elevations, which suggests lack of seeding success and potential inefficiency of seeding efforts involving this species on such sites. Demonstrated increases in spread with time since seeding suggest that, although negative effects on plant communities in adjacent unseeded areas might not occur instantaneously, they may develop over time. Native species are critical for the perpetuation of resilient ecosystem functioning (Richards et al. 1998); expanded research on effects of highly competitive introduced species such as $K$. prostrata on native plants is needed to inform rehabilitation efforts. Knowledge of environmental and disturbance variables associated with increased abundance and spread, coupled with enhanced understanding of effects on native plant communities, will enable land managers to make ecologically informed decisions regarding use of $K$. prostrata. If management objectives include increasing species or functional diversity or native species abundance, use of $K$. prostrata may not be effective.

\section{ACKNOWLEDGMENTS}

The authors would like to thank Matthew Gray for field assistance. Bruce McCune, David Pyke, and Andrea Thorpe, all of Oregon State University, offered help with statistical analysis and guidance. Many thanks to Roger Rosentreter of the Idaho BLM for help with logistics and support. This work would not have been possible without the assistance of many state and federal employees throughout Idaho and Oregon, and thanks are extended to all. Finally, we thank the Associate Editor, Cindy Salo, and an anonymous reviewer for constructive comments.

\section{LITERATURE CITED}

Archer, S., and D. A. PYke. 1991. Plant-animal interactions affecting plant establishment and persistence on revegetated rangeland. Journal of Range Management 44:558-565.

Balyan, G. A. 1972. Prostrate summer cypress and its culture in Kirghizia. Isdatel'stvo, Frunze, Kirghizstan: National Technical Information Service. TT7759026. 294 p.

BeLnAP, J., AND D. J. EldRIDGE. 2001. Disturbance and recovery of biological soil crusts. In: J. Belnap and O. L. Lange [EDS.]. Biological soil crusts: structure, function, and management. New York, NY, USA: Springer Verlag. p. 363-384.

BelnaP, J., AND S. L. Phillips. 2001. Soil biota in an ungrazed grassland: response to annual grass (Bromus tectorum) invasion. Ecological Applications 11:12611275. 
Bllbrough, C. J., AND J. H. Richards. 1993. Growth of sagebrush and bitterbrush following simulated winter browsing: mechanisms for tolerance. Ecology 74:481-492.

Brooks, M. L., And D. A. Pyke. 2001. Invasive plants and fire in the deserts of North America. In: K. E. M. Galley and T. P. Wilson [EDS.]. Proceedings of the Invasive Species Workshop: the role of fire in the control and spread of invasive species. Fire Conference 2000: The First National Congress on Fire Ecology, Prevention, and Management; 27 November-1 December 2000; San Diego, CA, USA. Tallahassee, FL, USA: Tall Timbers Research Station. Miscellaneous Publication No. 11. p. 1-14.

Chambers, J. C., R. W. Brown, and B. D. Willams. 1994. An evaluation of reclamation succession on Idaho's phosphate mines. Restoration Ecology 2:4-16.

Chambers, J. C., E. Leger, and E. Goergen. 2009. Cold desert fire and invasive species management: resources, strategies, tactics, and response. Rangelands $31(3): 14-20$

Chambers, J. C., B. A. Roundy, R. R. Blank, S. E. Meyer, and A. Whittaker. 2007. What makes Great Basin sagebrush ecosystems invasible by Bromus tectorum? Ecological Monographs 77:117-145.

Chambers, J. C., And M. J. Wisdom. 2009. Priority research and management issues for the imperiled Great Basin of the western United States. Restoration Ecology 17:707-714

Chen, S. P., Y. F. Bal, G. H. Lin, Y. Liang, And X. G. Han. 2005. Effects of grazing on photosynthetic characteristics of major steppe species in the Xilin River Basin, Inner Mongolia, China. Photosynthetica 43:559-565.

DavenPoRT, B. W. 2005. Cattle utilization of forage kochia (Kochia prostrata) and its relation to forage quality and plant morphological characteristics [thesis]. Logan, UT, USA: Utah State University. 75 p.

DuKES, J. S., AND H. A. Mooney. 1999. Does global change increase the success of biological invaders? Trends in Ecology \& Evolution 14:135-139.

Duniway, M. C., B. T. Bestelmeyer, and A. Tugel. 2010. Soil processes and properties that distinguish ecological sites and states. Rangelands 32(6):9-15.

Eissenstat, D. M., and M. M. Caldwell. 1988. Competitive ability is linked to rates of water extraction. Oecologia 75:1-7.

Eiswerth, M. E., K. Krauter, S. R. Swanson, and M. Zielinski. 2009. Post-fire seeding on Wyoming big sagebrush ecological sites: regression analyses of seeded nonnative and native species densities. Journal of Environmental Management 90:1320-1325.

ELDRIDGE, D. 2004. Mounds of the American badger (Taxidea taxus): significant features of North American shrub-steppe ecosystems. Journal of Mammalogy 85:1060-1067.

EldRidge, D., and M. Wicklow-Howard. 2004. Post-fire recovery of microbiotic soil crusts. Final year monitoring results for two sites on the Lower Snake River District, BLM. Boise, ID, USA: USDI-BLM and Boise State University. 16 p.

[ESRI] Environmental Systems Research Institute Incorporated. 2009. ArcMap GIS Software, Version 9.3.1. Redlands, CA, USA: ESRI.

Evans, R. D., R. Rimer, L. SperRy, and J. Belnap. 2001. Exotic plant invasion alters nitrogen dynamics in an arid grassland. Ecological Applications 11:1301-1310.

Federal Register. 2009. Endangered and threatened wildlife and plants; listing Lepidium papilliferum (slickspot peppergrass) as a threatened species throughout its range. Washington, DC, USA: US Department of the InteriorFish and Wildlife Service. Final rule 8 October 2009, Volume 74, Number 194. p. 52013-52064. Available at: http://frwebgate.access.gpo.gov/cgi-bin/getdoc cgi?dbname=2009_register\&docid=fr08oc09-17. Accessed 1 0ctober 2010.

Gelbard, J. L., AND J. Belnap. 2003. Roads as conduits for exotic plant invasions in a semiarid landscape. Conservation Biology 17:420-432.

Gray, E. C. 2011. An evaluation of the invasion potential of Kochia prostrata (forage kochia) in southwestern Idaho, USA [thesis]. Corvallis, OR, USA: Oregon State University. $73 p$

HarRISON, R. D. 2004. Adaptation and compatibility of forage kochia. In: D. Zobell, B. Waldron, and K. Wood [comps.]. Proceedings: Forage kochia workshop and tour; 9-10 November 2004; Logan, UT, USA. Logan, UT, USA: Utah State University. p. 16-18.

Harrison, R. D., N. J. Chatterton, B. L. Waldron, B. W. Davenport, A. J. Palazzo, W. H. HORTON, AND K. H. AsAy. 2000. Forage kochia: its compatibility and potential aggressiveness on intermountain rangelands. Logan, UT, USA: Utah State University. Utah Agricultural Experiment Station Research Report 162. 66 p.
Harrison, R. D., B. L. Waldron, K. B. Jensen, R. Page, T. A. Monaco, W. H. Horton, and A. J. PALAzzo. 2002. Forage kochia helps fight range fires. Rangelands 24(5):3-7.

Hickman, K. R. 2004. Grazing management effects on plant species diversity in tallgrass prairie. Journal of Range Management 57:58-65.

Hulet, A., B. A. Roundy, AND B. Jessop. 2010. Crested wheatgrass control and native species establishment in Utah. Rangeland Ecology \& Management 63:450-460.

Idaho Geospatial Data Clearinghouse. 2004. Digital elevation of Tile 07, Idaho with a horizontal grid spacing of 10-meters. Moscow, ID, USA: Idaho Geospatial Data Clearinghouse. Available at: http://data.insideidaho.org/data/IGDC/archive/ elev10m/elev10m_tile07_igdc.tgz. Accessed 10 January 2010.

Jones, T. A. 1999. Use of native plants for sagebrush steppe restoration. In: P. G. Entwistle, A. M. Debolt, J. H. Kaltenecker, and K. Steenhof [EDS.]. Proceedings: Sagebrush steppe ecosystems symposium; 21-23 June 1999; Boise, ID, USA. Boise, ID, USA: Boise State University. p. 73-77.

Karimi, G., M. Ghorbanli, H. Heidari, R. A. Khavari Nejad, and M. H. Assareh. 2005. The effects of $\mathrm{NaCl}$ on growth, water relations, osmolytes and ion content in Kochia prostrata. Biologia Plantarum 49:301-304.

KruSKaL, J. B. 1964. Nonmetric multidimensional scaling: a numerical method. Psychometrika 29:115-129.

Leonard, E. D., T. A. Monaco, J. M. Stark, and R. J. Ryel. 2008. Invasive forb, annual grass, and exotic shrub competition with three sagebrush steppe growth forms: acquisition of a spring ${ }^{15} \mathrm{~N}$ tracer. Invasive Plant Science and Management $1: 168-177$.

LYM, R. G., AND D. R. KIRBY. 1987. Cattle forage behavior in leafy spurge (Euphorbia esula)-infested rangeland. Weed Technology 1:314-318.

Mack, R. N., D. Simberloff, W. M. Lonsdale, H. Evans, M. Clout, and F. A. Bazzaz. 2000. Biotic invasions: causes, epidemiology, global consequences, and control. Ecological Applications 10:689-710.

McArthur, E. D., A. C. Blauer, and R. Stevens. 1990. K. prostrata competition with cheatgrass in central Utah. In: E. D. McArthur, E. M. Romney, S. D. Smith, P. T. Tueller [comps.]. Proceedings: symposium on cheatgrass invasion, shrub die-off, and other aspects of shrub biology and management; 5-7 April 1989; Las Vegas, NV, USA. Ogden, UT, USA: USDA Forest Service Intermountain Research Station. Gen. Tech. Report INT-276. p. 351.

McCune, B. 2006. Non-parametric habitat models with automatic interactions. Journal of Vegetation Science 17:819-830.

McCune, B., And J. B. Grace. 2002. Analysis of ecological communities. 2nd printing. Gleneden Beach, OR, USA: MjM Software. 300 p.

McCune, B., AND M. J. MefFoRD. 2009. HyperNiche. Nonparametric multivariate habitat modeling. Version 2.10. Gleneden Beach, OR, USA: MjM Software.

McCune, B., And M. J. Mefrord. 2011. PC-ORD. Mulitvariate analysis of ecological data. Version 6.0. Gleneden Beach, OR, USA: MjM Software.

Meinke, C. W., S. T. Knick, AND D. A. PYke. 2009. A spatial model to prioritize sagebrush landscapes in the Intermountain West (USA) for restoration. Restoration Ecology 17:652-659.

Melgoza, G., And R. S. Nowak. 1991. Competition between cheatgrass and two native species after fire: implication from observations and measurements in root distribution. Journal of Range Management 44:27-33.

Miller, R. F., S. T. Knick, D. A. Pyke, C. W. Meinke, S. E. Hanser, M. J. Wisdom, and A. L. HILD. 2011. Characteristics of sagebrush habitats and limitations to long-term conservation. In: S. T. Knick and J. W. Connelly [EDS.]. Greater sage-grouse: ecology and conservation of a landscape species and its habitats. Studies in avian biology. Vol. 38. Berkeley, CA, USA: University of California Press. p. 145184.

Monaco, T. A., B. L. Waldron, R. L. Newhall, and W. H. Horton. 2003. Re-establishing perennial vegetation in cheatgrass monocultures. Rangelands 25(2):26-29.

Moody, M. E., AND R. N. MACK. 1988. Controlling the spread of plant invasions: the importance of nascent foci. Journal of Applied Ecology 25:1009-1021.

Moseley, R. K. 1994. Report on the conservation status of Lepidium papilliferum. Boise, ID, USA: Idaho Conservation Data Center, Idaho Department of Fish and Game. $35 \mathrm{p}$.

Newhall, R. L., T. A. Monaco, W. H. Horton, R. D. Harrison, and R. J. Page. 2004. Rehabilitating salt-desert ecosystems following wildfire and wind erosion. Rangelands 26(1):3-7.

Noss, R. F., E. T. LaRoe III, and J. M. Scott. 1995. Endangered ecosystems of the United States: a preliminary assessment of loss and degradation. Washington, 
DC, USA: USDI-National Biological Service. Report 28. 58 pp. Available at: http:// biology.usgs.gov/pubs.ecosys.htm. Accessed 27 January 2012.

Palge, C., And S. A. RitTer. 1999. Birds in a sagebrush sea: managing sagebrush habitats for bird communities. Boise, ID, USA: Partners in Flight Western Working Group. 47 p.

Participants of the Snake River Birds of Prey nCA Habitat Restoration Workshop. 1999. Snake River Birds of Prey NCA habitat restoration summary and recommendations. In: P. G. Entwistle, A. M. Debolt, J. H. Kaltenecker, and K. Steenhof [comps.]. Proceedings: sagebrush steppe ecosystems symposium; 21-23 June 1999; Boise, ID, USA. Boise, ID, USA: Boise State University. p. 91-97.

Pellant, M. 1994. History and applications of the Intermountain greenstripping program. In: S. B. Monsen and S. G. Kitchen [EDS.] Proceedings of the Ecology and Management of Annual Rangelands; 18-21 May 1992; Boise, ID, USA. Washington, DC, USA: USDA Forest Service. General Technical Report INT-313. p. 63-68.

Pellant, M., B. Abbey, and S. Karl. 2004. Restoring the Great Basin desert, USA: integrating science, management, and people. Environmental Monitoring and Assessment 99:169-179.

Pellant, M., and S. B. Monsen. 1993. Rehabilitation on public rangelands in Idaho, USA: a change in emphasis from grass monocultures. Proceedings of the XVII International Grassland Congress; 8-21 February 1993; Palmerston North, Hamilton, and Lincoln, New Zealand, and Rockhampton, QLD, Australia. New Zealand Grassland Association, Tropical Grasslands Society of Australia, New Zealand Society of Animal Production, Australian Society of Animal ProductionQueensland Branch, and New Zealand Institute of Agricultural Science. Palmerston North, New Zealand: Keeling \& Mundy. p. 778-779.

Ponzetti, J. M., B. McCune, And D. A. Pyke. 2007. Biotic soil crusts in relation to topography, cheatgrass, and fire in the Columbia Basin, WA. The Bryologist 113:292-307.

Ponzetti, J. M., And B. P. McCune. 2001. Biotic soil crusts of Oregon's shrub steppe: community composition in relation to soil chemistry, climate, and livestock activity. The Bryologist 104:212-225.

The PRISM Climate Group, Oregon State University. 2006. United States average monthly or annual precipitation, 1971-2000. Corvallis, OR, USA: PRISM Climate Group, Oregon State University. Available at: http://www.prism.oregonstate.edu/products/ viewer.phtml?file=/pub/prism/us_30s/grids/ppt/Normals/us_ppt_1971_2000.14. gz\&year=1971_2000\&vartype=ppt\&month=14\&status=final. Accessed 15 September 2010.

Pyankov, V. I., E. G. Artyusheva, G. E. Edwards, C. C. Black, JR., and P. S. Soltis. 2001. Phylogenetic analysis of tribe Salsoleae (Chenopodiaceae) based on ribosomal ITS sequences: implications for the evolution of photosynthetic types. American Journal of Botany 88:1189-1198.

PYKE, D. A., AND S. T. KNICK. 2003. Plant invaders, global change and landscape restoration. In: N. Allsopp, A. R. Palmer, S. J. Milton, K. P. Kirkman, G. I. H. Kerley, C. R. Hurt, and C. J. Brown [EDS.]. Proceedings VIlth International Rangelands Congress; 26 July-1 August 2003; Durban, South Africa. p. 278288.

Richards, R. T., J. C. Chambers, and C. Ross. 1998. Use of native plants on federal lands: policy and practice. Journal of Range Management 51:625-632.

Romo, J. T., AND M. R. Haferkamp. 1987. Forage kochia germination response to temperature, water stress, and specific ions. Agronomy Journal 79:27-30.

Stevens, R., K. R. Jorgensen, E. D. McArthur, and J. N. Davis. 1985. "Immigrant" forage kochia. Rangelands 7:22-23.

Thompson, T. W., B. A. Roundy, E. D. McArthur, B. D. Jessop, B. Waldron, and J. N. Davis. 2006. Fire rehabilitation using native and introduced species: a landscape trial. Rangeland Ecology \& Management 59:237-248.

Thorpe, A. S., E. T. Aschehoug, D. Z. Atwater, and R. M. Callaway. 2011. Interactions among plants and evolution. Journal of Ecology 99:729-740.
TuAson, T. 2005. 1987-2004 monitoring results of Lepidium davisii in the Mountain Home District. Boise, ID, USA: USDI-BLM, Boise District. 70 p.

US Department of Agriculture-Farm Service Agency, Aerial Photography Field Office [USDA-FSA-APF0]. 2009. Digital orthoimagery series of Idaho, 2009, 1-meter, natural color and false color series. Salt Lake City, UT, USA: USDA-FSA-APFO. Available at: http://cloud.insideidaho.org/data/imageryBaseMapsEarthCover/ orthoimagery/2009_1m_idaho/2009naturalColorAndIR_1m_idaho.lyr. Accessed 20 July 2010.

[USDA-NCRS] US Department of Agriculture-Natural Resources Conservation Service. 2008. Soil survey geographic (SSURGO) database. Soil surveys for Ada, Elmore, Payette, Owyhee, and Twin Falls Counties, Idaho. Fort Worth: TX, USA: USDANRCS. Available at: http://greatbasin.wr.usgs.gov/ltdl/Default.aspx. Accessed 2 August 2010.

USDA-NRCS. 2011. The PLANTS database. Baton Rouge, LA, USA: National Plant Data Center. Available at: http://plants.usda.gov. Accessed 3 January 2011.

[USDI-BLM] US Department of the Interior-Bureau of Land Management. 2007. Burned area emergency stabilization and rehabilitation handbook (public) $\mathrm{H}-1742-1$. $\mathrm{p}$. 38. Available at: http://www.blm.gov/pgdata/etc/medialib/b/m/wo/ Information_Resources_Management/policy/blm_handbook.Par.52739.File.dat/ h1742-1.pdf. Accessed 27 September 2010.

uSDi-Blm Idaho State Offices, Engineering and Geographic Sciences. 2009a. Range allotments of Idaho. Boise, ID, USA: USDI-BLM. Available at: http://data. insideidaho.org/util/zip.ashx?fn=http://data.insideidaho.org/data/BLM/downdata/ statewide/rngAllotment_id_blm.zip. Accessed 1 June 2010.

uSDi-Blm Boise District, Twin Falls District Office, Idaho Falls District Office, Idaho StATE OFFICE. 2009b. Historic wildfire perimeters [1937-2008] on or adjacent to Bureau of Land Management administered lands in Idaho. Boise, ID, USA: USDIBLM. Available at: http://data.insideidaho.org/util/zip.ashx?fn=http://data. insideidaho.org/data/BLM/downdata/statewide/wildfire_id_blm.zip. Accessed 25 September 2010.

USDI-BLM. 2010. Twin Falls District wildlife tracts habitat enhancement. Washington, DC, USA: USDI-BLM. Environmental assessment ID-210-2008-EA-248. $11 \mathrm{p}$.

[USDI-FWS] USDI-FISH AND WILDLIFE SERVICE 2010. Biological opinion on the effects of Bureau of Land Management ongoing livestock grazing actions in Idaho on the slickspot peppergrass (Lepidium papilliferum). Boise, ID, USA: USDI-FWS. Report 14420-2010-F-0025. 307 p.

Vitousek, P. M., C. D. Antonio, L. L. Loope, M. Rejmánek, and R. Westbrooks. 1997. Introduced species: a significant component of human caused global change. New Zealand Journal of Ecology 21:1-16.

Waldron, B. L., B. W. Davenport, J. C. Malechek, and K. B. Jensen. 2010. Relative cattle preference of 24 forage kochia (Kochia prostrata) entries and its relation to forage nutritive value and morphological characteristics. Crop Science 50:2112-2123.

Waldron, B. L., J.-S. Eun, D. R. ZobelL, And K. C. OLson. 2010. Forage kochia (Kochia prostrata) for fall and winter grazing. Small Ruminant Research 91:47-55.

Waldron, B. L., R. D. Harrison, N. J. Chatterton, and B. W. Davenport. 2001. Forage kochia: friend or foe. In: D. D. McArthur and D. J. Fairbanks [comps.]. Shrubland ecosystem genetics and biodiversity: proceedings; 13-15 June 2000; Provo, UT, USA. Ogden, UT: USDA Forest Service. Proceedings RMRS-P-21. p. 210-215.

Western Regional Climate Center. 2008. Mountain Home Idaho, period of record monthly climate summary: 8/1/1948 to 12/31/2005. Available at: http://www. wrcc.dri.edu/cgi-bin/cliMAIN.pl?idmoun. Accessed 15 September 2010.

Wisdom, M. J., AND J. C. Chambers. 2009. A landscape approach for ecologically based management of Great Basin shrublands. Restoration Ecology 17:740-749.

ZHAO, W. Y., J. L. LI, AND J. G. QI. 2007. Changes in vegetation diversity structure in response to heavy grazing pressure in the northern Tianshan Mountains, China. Journal of Arid Environments 68:465-479. 